\title{
Heavy Metal Profile of Oreochromis niloticus Harvested from E-Waste Polluted Vials and Associated Fungi
}

\author{
Adeyemi Isaac Sanusi \\ Department of Microbiology, Federal University of Technology, Akure, Nigeria \\ Email: Sanusi_isaac@yahoo.com
}

Received 5 March 2016; accepted 17 July 2016; published 20 July 2016

Copyright (C) 2016 by author and Scientific Research Publishing Inc.

This work is licensed under the Creative Commons Attribution International License (CC BY).

http://creativecommons.org/licenses/by/4.0/

(c) (i) Open Access

\section{Abstract}

This study was designed to investigate the possible variation in bioaccumulation of heavy metals (lead, cadmium, zinc, cobalt, chromium, nickel, and manganese) in the tissue of harvested Oreochromis niloticus (tilapia) and the associated fungi from vials treated with soil from e-waste dumpsite and soil without e-waste. E-waste is electronic waste which contains valuable metals as well as potential environmental contaminants. The heavy metals in soil and fish samples were determined using flame atomic absorption spectrophotometer (AAS) after homogeneity and digestion of samples. The associated fungi were identified using standard microbiological methods. The genera of the associated fungi were: Penicillium, Candida, Articulospora, Aspergillus, Aspergillus, Aspergillus, Rhizopus, Mucor, Zoopage, Varicosporium and Rhodoturula. The quantity of fungi isolated from each pollution treatments showed that the number of fungi were inversely proportional to the quantity of e-waste soil pollution and directly proportional to the quantity of soil without e-waste pollution. The occurrence of the fungi species revealed that the untreated (control) vial had the highest occurrence (191) while the lowest occurrence (103) occurred in the vial polluted with the highest quantity of soil from e-waste dumpsite. The $\mathrm{pH}$ and the biochemical oxygen demand (BOD) of the vials were significantly affected by the pollutions. Variations were also observed in the bioaccumulation of the heavy metals by Oreochromis niloticus. Cadmium $(0.01 \mathrm{mg} / \mathrm{kg})$ and nickel $(0.02$ $0.08 \mathrm{mg} / \mathrm{kg}$ ) were the least recorded metal in the tissue of the fish while cobalt was not detected after the five weeks period. The sequence of the heavy metals concentrations in Oreochromis niloticus tissue samples was $\mathrm{Zn}>\mathrm{Mn}>\mathrm{Pb}>\mathrm{Cr}>\mathrm{Ni}>\mathrm{Cd}>\mathrm{Co}$. The accumulation of the metals in the fish tissue were, however, lower than the international maximum guidelines, except for manganese $(0.29-3.13 \mathrm{mg} / \mathrm{kg})$ that exceeded the $0.01-0.05 \mathrm{mg} / \mathrm{kg}$ threshold levels for manganese by Federal Environmental Protection Agency (FEPA). Protecting the environments from toxic metals is necessary, hence a need for public awareness on the dangers of these toxic metals and law for proper disposal of e-waste. 
Keywords

Bioaccumulation, Fungi, Heavy Metals, Vial, E-Waste Soil, Oreochromis niloticus

\section{Introduction}

Electronic waste (e-waste) includes an increasing range of electronic appliances from large household appliances, such as refrigerators, air-conditioners, cell phones, stereo systems and consumable electronic items to computers discarded by their users [1]. Electronic waste contains valuable metals as well as lead, mercury, nickel, selenium, cadmium, polybrominated diphenyl ethers, and polychlorinated biphenyls which are potentially environmental contaminants. E-waste is commonly disposed in landfills. Although illegal under the Basel Convention, developed and wealthy countries export large quantities of electronic waste to less developed countries, where the processes of recycling include burning and dissolution in strong acids with less consideration to protect human health and the environment. Such reprocessing initially leads to extreme localized pollution followed by migration of the pollutants into receiving aquatic environments (usually as non-point sources) and food chains [1] [2].

In aquatic environments, larger organisms such as fish have been exposed to heavy metals as a direct consequence of biomagnifications [3]. The danger is that heavy metals even at low concentrations in fish and water have a particular significance in ecotoxicology and their effects have been well documented [4]-[8]. [9] reported a concentration of $0.13 \mathrm{mg} / \mathrm{kg}$ manganese and $0.62 \mathrm{mg} / \mathrm{kg}$ cadmium in fish. There are recommended limits of individual elements in water and fish [10]. Fishes are the aquatic inhabitants that cannot escape from the toxic effects of heavy metal pollution as a result of their contact with water that carries the heavy metals in solution [8]. The importance of fish in the diet of man cannot be over emphasized and therefore, there is a need to monitor the water quality for fish culturing and the water from which fish is harvested in the natural environment alongside routine screening of fish for heavy metal concentration to limit transfer of heavy metals to man through fish consumption. Water bodies are polluted by run offs, industrial waste discharge and solid waste. This is common in cities closed to water bodies such as lakes, rivers, sea. E-waste (an example of solid waste) disposal can lead to increase in heavy metals concentrations in the environment and in the tissues of living organisms interacting with the polluted environment. When a river in China received discharged waste water from a nearby e-waste processing plant, the organisms in the river had increased heavy metals concentrations in their tissues [11]. Such pollution put living organisms at risk of heavy metal toxicity and human inhabitants relying on such water are also at risk. Lagos State is one of the coastal states in Nigeria, where Alaba International Market is located. This market is known for sales of electronic products both new and fairly used ones. It also has a dumpsite where tons of e-waste are dumped annually. This e-waste dumpsite is close to Lagos lagoon. Run offs from this e-waste dumpsite can easily reach the lagoon, thereby increasing the concentrations of heavy metals released to the lagoon water. This will expose both the micro and macro organisms (including man) to heavy metal toxicity. Hence, the results in this research are geared towards raising public awareness on the danger of improper disposal of e-waste and to provide baseline data on e-waste pollution of aquatic environment.

\section{Materials and Methods}

\subsection{Collection of Soil Sample and Fish Used}

The sample collection point was e-waste dumpsite Alaba International Market, Lagos State, Nigeria. Soil samples were obtained using soil auger at depths of $6 \mathrm{~cm}$. The samples were collected in sterile containers and taken for physiochemical and microbiological analysis. The soil samples were homogenized before further physiochemical analyses (but for heavy metals flame atomic absorption spectrophotometer (AAS) was used after the digestion of homogenized soil samples) [12] [13]. Fishes used were obtained from the Department of Fish and Aquaculture Technology, Federal University of Technology, Akure $\left(7.23^{\circ} \mathrm{N}, 5.15^{\circ} \mathrm{E}\right)$, Ondo State $\left(7^{\circ} 10^{\prime} \mathrm{N}, 5^{\circ} 05^{\prime} \mathrm{E}\right)$, Nigeria $\left(9.08^{\circ} \mathrm{N}, 8.68^{\circ} \mathrm{E}\right)$.

\subsection{Set up and Pollution of Aquaria}

A set of seven vials, each containing six juvenile tilapia fish, were treated with three different quantities of the 
e-waste soil sample and soil without e-waste ( $25 \mathrm{~g}, 50 \mathrm{~g}$ and $75 \mathrm{~g}$ for both soil samples) in the ratio of $25 \mathrm{~L}: 25 \mathrm{~g}$, 25 L:50 g, 25 L:75 g of water to soil samples after acclimatization of the fishes for six weeks. The seventh vial was the second control (vial without soil). The vials were monitored weekly for five weeks for $\mathrm{pH}$, dissolved oxygen, biochemical oxygen demand, while microbiological analyses of the vials water were performed by; weekly monitoring of fungal loads and isolation of fungi.

\subsection{Cultural and Microscopic Examination of Fungal Isolates}

Using microscope at low power magnification (40×), the cultural parameters such as colony colour, characteristics of the submerged hyphae rhizoid of mature fruiting bodies were all observed. A small piece of mycelium was transferred using a sterile inoculating loop unto a clean glass slide containing a drop of cotton blue-in-lactophenol and the mycelium spread properly. The preparation was covered with a clean grease free cover slip and observed under medium power $(100 \times)$. The observations made were used to identify the microscopic characteristics of the fungi species [14].

\subsection{Fungi Spore Count}

Visible spores that appeared on the plates were counted. The spore forming unit (sfu) per ml was determined based on the volume of the sample used.

\subsection{Physicochemical Parameters}

Organic carbon determination and Organic matter [15], total phosphate determination and nitrogen determination [16], heavy metals determination in soil samples using AAS [17], biochemical oxygen demand [18], temperature and $\mathrm{pH}$ [19] were the physiochemical parameters determined.

\subsection{Heavy Metals Bioaccumulation Analysis}

Heavy metals in the tissue of the tilapia fish were analyzed by oven drying the whole fish, digest the fish (using wet digestion) and the heavy metals were determined using Atomic Absorption Spectrophotometer [15].

\section{Results and Discussion}

A total of eleven different fungi species were isolated from the e-waste soil sample, soil without e-waste sample and polluted fish vials, nine of which (Aspergillus niger, Aspergillus flavus, Articulospora inflata, Zoopagenitospora, Varicosporiumelodeae, Penicillium sp., Rhodoturula sp., Rhizopus stolonifer, and Mucormucedo) had also been isolated from crude oil polluted environment, other polluted areas, gastrointestinal tract and agricultural soil. Their presence in the soil samples and the vials could have been as a result of their ability to adapt to different environmental conditions and using wide ranges of substances as nutrient and energy sources [21]-[24]. Fungal colony count from each polluted vial showed that the quantity of fungi was inversely proportional to the quantity of e-waste soil pollution and directly proportional to the quantity of soil without e-waste pollution (Figure 1), indicating possible suppressing effect of the pollution on fungal growth in these vials [25]. E-waste soil and e-waste soil polluted fish vials had significant number of fungal isolates. This could be attributed to high percentage of organic contents and moisture content of the e-waste soil sample (Table 1), which might have encouraged the growth of these fungi [25].

A total of 956 fungi isolates were obtained from tilapia aquaria by the end of the five-week observation period (Tables 2-9). The occurrence of the fungi species revealed that the untreated vial has the highest number of fungi isolates (Table 2 and Table 9), consistent with a possible suppressing effect of soil pollutants. Aspergillus niger, Aspergillus flavus, Aspergillus repens, Articulospora inflata, Zoopagenitospora, Candida sp., Penicillium italicum, Rhizopus stolonifer, Mucormucedo, Varicosporiumelodeae and Rhodoturula sp. were isolated from vials with soils, regardless of electronic pollution. These microorganisms might have adapted to the presence of e-waste in this environment [26] and probably they can be manipulated in the biosorption of pollutants (especially the heavy metals) from e-waste. This agreed with the findings of [27], in the bio accumulating of heavy metals using Aspergillus lentulus, [28], using bacterial and protozoan species and [29] using yeast (Rhodotorula mucilaginosa). 


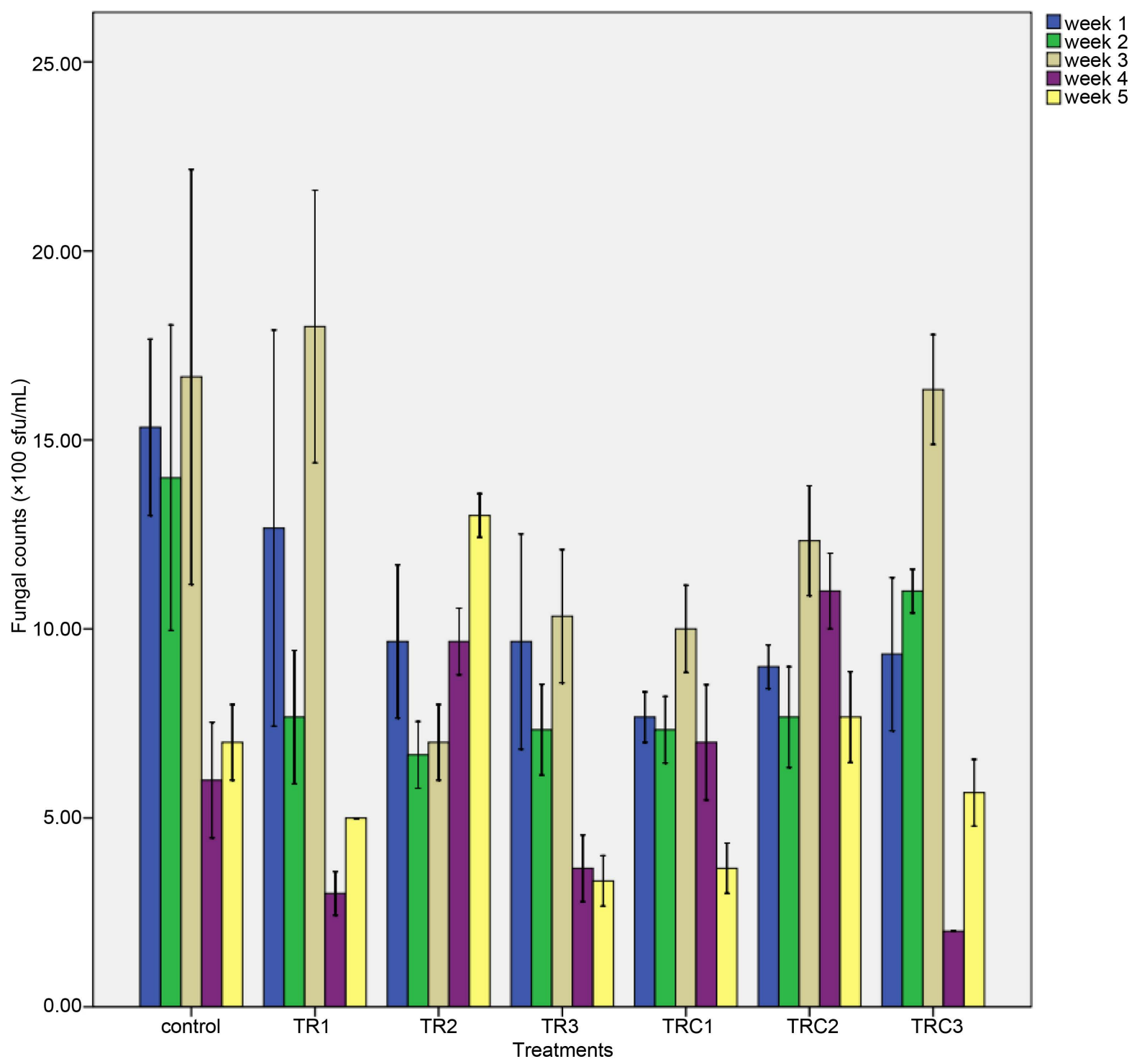

Figure 1. Weekly fungal count of tilapia fish vials. Key: TR1-Treated with $25 \mathrm{~g}$ of e-waste soil, TR2 - Treated with $50 \mathrm{~g}$ of e-waste soil, TR3 - Treated with $75 \mathrm{~g}$ of e-waste soil; TRC1-Treated with $25 \mathrm{~g}$ of soil without e-waste, TRC2 - Treated with $50 \mathrm{~g}$ of soil without e-waste, TRC3-Treated with $75 \mathrm{~g}$ of soil without e-waste.

Bioaccumulation of heavy metals occurred in tilapia (Oreochromis niloticus), this could be through oral consumption, the gills or the skin [30]. The sequence of the heavy metals concentrations in Oreochromis niloticus tissue samples was $\mathrm{Zn}>\mathrm{Mn}>\mathrm{Pb}>\mathrm{Cr}>\mathrm{Ni}>\mathrm{Cd}>\mathrm{Co}$ (Figure 2). The similarity in the order of magnitude in the heavy metal accumulated by the fishes from the polluted vials (especially the accumulation of zinc) is probably due to the same period spent in the different polluted vials and they are same species of fish with the same metabolic system and the same membrane function. The accumulations could also have been due to inability of the fishes to metabolize the heavy metals or poor metabolism of the heavy metals by the fish. The research also showed that cadmium and nickel were poorly accumulated while cobalt was not accumulated. Probably there is no pathway for their absorption by the fish or the presence of enzymes that could detoxify or metabolized the heavy metals could also lead to the results [31]. The maximum tolerable level for manganese was exceeded in tilapia tissue of one vial with e-waste (Mn accumulates from $0.29 \mathrm{mg} / \mathrm{kg}$ in Control to $3.13 \mathrm{mg} / \mathrm{kg}$ in TR3; Recommended limit is $0.01-0.05 \mathrm{mg} / \mathrm{kg}$ for manganese [32]. Therefore there is a potential risk (at least possible bioaccumulation and toxicity of manganese) to inhabitants that depend on river or water body polluted by e-waste. 
Table 1. Soil physiochemical parameters.

\begin{tabular}{|c|c|c|c|}
\hline $\mathbf{S} / \mathbf{N}$ & PARAMETER & Soil from e-waste dumpsite & Soil without e-waste \\
\hline 1. & Colour & Black & Brown \\
\hline 2. & Texture & Sandy-loamy & Sandy \\
\hline 3. & $\mathrm{pH}$ & 7.90 & 8.70 \\
\hline 4. & Moisture content (\%) & 3.86 & 2.24 \\
\hline 5. & Organic matter (\%) & 17.60 & 5.00 \\
\hline 6. & Organic carbon (\%) & 10.17 & 2.89 \\
\hline 7. & Organic nitrogen (\%) & 0.35 & 0.21 \\
\hline 8. & Organic phosphorus (mg/kg) & 146.65 & 160.00 \\
\hline 9. & Lead (mg/kg) & 64.90 & 3.06 \\
\hline 10. & Cadmium (mg/kg) & 0.32 & 0.02 \\
\hline 11. & Zinc (mg/kg) & 35.50 & 3.34 \\
\hline 12. & Cobalt (mg/kg) & 0.83 & 0.05 \\
\hline 13. & Chromium (mg/kg) & 0.54 & 0.26 \\
\hline 14. & Manganese (mg/kg) & 18.60 & 2.99 \\
\hline 15. & Nickel (mg/kg) & 2.82 & 0.08 \\
\hline 17. & Sodium (mg/kg) & 24.40 & 31.40 \\
\hline 18. & Potassium (mg/kg) & 33.30 & 32.90 \\
\hline 19. & Calcium (mg/kg) & 182.00 & 245.00 \\
\hline 20. & Magnesium (mg/kg) & 34.00 & 29.70 \\
\hline
\end{tabular}

(Source: [20]).

Table 2. Fungal species isolated from the e-waste soil and the soil without e-waste.

\begin{tabular}{cc}
\hline E-waste soil & Soil without e-waste \\
\hline Candida sp. & Candida sp. \\
Zoopagenitospora & Articulospora inflata \\
Articulospora inflata & \\
Varicosporiumelodeae & \\
\hline
\end{tabular}

This variation in $\mathrm{pH}$ could have been as a result of succession of the microorganisms in vials and their different fermentative activities [33]. The $\mathrm{pH}$ in the vials shifted from slightly acidic (6.60 - 7.05) in week 1 to neutrality (6.85 - 7.60) in weeks 2 - 5 (Figure 3). Vials polluted with soil without e-waste had higher pH values compared to vials polluted with e-waste soil.

The biochemical oxygen demand (BOD) in vials showed no noticeable differences between the soil types (e-waste soil and soil without e-waste) pollution, with week 2 - 5 having higher BOD than the first week (Figure 4). These could be due to similarity in the rate of release of metabolites by tilapia in the vials.

\section{Conclusion}

It was apparent from the present study that fungi population and fungi community were influenced by the ewaste presence. Fungi community and activities might eventually be affected by the e-waste presence, if e-waste 
Table 3. Occurrence of fungi in tilapia control vial.

\begin{tabular}{|c|c|c|c|c|c|c|}
\hline Fungi species & Week 1 & Week 2 & Week 3 & Week 4 & Week 5 & Total \\
\hline Penicillium italicum & - & 2 & 4 & 4 & 1 & 11 \\
\hline Articulospora inflate & 4 & 6 & 12 & 7 & 7 & 36 \\
\hline Candida sp. & 38 & 14 & 11 & 3 & 9 & 65 \\
\hline Aspergillus niger & - & - & - & 1 & - & 1 \\
\hline Rhodoturula sp. & 14 & 15 & 9 & - & - & 38 \\
\hline Mucormucedo & - & 3 & - & - & - & 3 \\
\hline Aspergillus flavus & - & 1 & 11 & 1 & 16 & 29 \\
\hline Rhizopus stolonifera & - & 1 & - & 1 & - & 2 \\
\hline Varicosporiumelodeae & - & - & 3 & - & 1 & 4 \\
\hline Zoopagenitospora & - & - & - & 1 & 1 & 2 \\
\hline Total & & & & & & 191 \\
\hline
\end{tabular}

Table 4. Occurrence of fungi in tilapia TR1 vial.

\begin{tabular}{|c|c|c|c|c|c|c|}
\hline Fungi species & Week 1 & Week 2 & Week 3 & Week 4 & Week 5 & Total \\
\hline Penicillium italicum & - & 1 & 4 & - & - & 5 \\
\hline Articulospora inflate & 1 & 4 & 8 & 8 & 5 & 26 \\
\hline Candida sp. & 8 & 10 & 17 & 8 & 5 & 49 \\
\hline Aspergillus niger & 2 & 1 & - & - & 1 & 4 \\
\hline Rhodoturula sp. & 15 & 10 & 10 & - & - & 35 \\
\hline Mucormucedo & - & - & - & - & 1 & 1 \\
\hline Aspergillus flavus & - & - & 11 & - & 4 & 15 \\
\hline Rhizopus stolonifera & 8 & 1 & 1 & - & - & 10 \\
\hline Varicosporiumelodeae & - & - & 4 & - & - & 4 \\
\hline Zoopagenitospora & - & - & - & - & 4 & 4 \\
\hline Aspergellusrepens & - & 1 & - & 1 & - & 2 \\
\hline Aureobasidium pullulans & 4 & - & - & - & - & 4 \\
\hline Total & & & & & & 140 \\
\hline
\end{tabular}

Table 5. Occurrence of fungi in tilapia TR2 vial.

\begin{tabular}{|c|c|c|c|c|c|c|}
\hline Fungi species & Week 1 & Week 2 & Week 3 & Week 4 & Week 5 & Total \\
\hline Penicillium italicum & - & - & - & 8 & - & 8 \\
\hline Articulospora inflate & 2 & 3 & 10 & 4 & 7 & 26 \\
\hline Candida sp. & 5 & 6 & - & 1 & 4 & 16 \\
\hline Aspergillus niger & 2 & 1 & 2 & - & - & 5 \\
\hline Rhodoturula sp. & 15 & 6 & 2 & - & - & 23 \\
\hline Aureobasidium pullulans & 2 & 4 & - & - & - & 6 \\
\hline Aspergillus flavus & - & - & 2 & 14 & 4 & 20 \\
\hline Rhizopus stolonifera & 3 & - & 1 & 1 & - & 5 \\
\hline Varicosporiumelodeae & - & - & 4 & - & 2 & 6 \\
\hline Zoopagenitospora & - & - & - & - & 9 & 9 \\
\hline Aspergellusrepens & - & - & - & 1 & 13 & 14 \\
\hline Total & & & & & & 138 \\
\hline
\end{tabular}


Table 6. Occurrence of fungi in tilapia TR3 vial.

\begin{tabular}{|c|c|c|c|c|c|c|}
\hline Fungi species & Week 1 & Week 2 & Week 3 & Week 4 & Week 5 & Total \\
\hline Penicillium italicum & - & 1 & 6 & 1 & - & 8 \\
\hline Articulospora inflate & - & 5 & 8 & 6 & 4 & 23 \\
\hline Candida sp. & 6 & 5 & - & 3 & - & 14 \\
\hline Aspergillus niger & 5 & 1 & 1 & - & - & 7 \\
\hline Aureobasidium pullulans & 9 & 1 & - & - & - & 10 \\
\hline Rhodoturula sp. & 7 & 2 & 2 & - & - & 11 \\
\hline Aspergillus flavus & - & 4 & 9 & 1 & 1 & 15 \\
\hline Rhizopus stolonifera & 2 & 1 & 2 & - & - & 5 \\
\hline Varicosporiumelodeae & - & - & 3 & - & 2 & 5 \\
\hline Zoopagenitospora & - & - & - & - & 1 & 1 \\
\hline Aspergellusrepens & - & 2 & - & - & 2 & 4 \\
\hline Total & & & & & & 103 \\
\hline
\end{tabular}

Table 7. Occurrence of fungi in tilapia TRC1 vial.

\begin{tabular}{|c|c|c|c|c|c|c|}
\hline Fungi species & Week 1 & Week 2 & Week 3 & Week 4 & Week 5 & Total \\
\hline Penicillium italicum & - & - & 1 & - & - & 1 \\
\hline Articulospora inflate & - & 4 & 6 & 4 & 2 & 16 \\
\hline Candida sp. & 4 & 9 & 1 & 3 & 1 & 18 \\
\hline Aspergillus niger & 6 & 1 & - & - & 1 & 8 \\
\hline Rhodoturula sp. & 9 & 5 & 2 & - & - & 16 \\
\hline Mucormucedo & - & - & 6 & - & - & 6 \\
\hline Aspergillus flavus & - & - & 8 & 12 & 3 & 23 \\
\hline Rhizopus stolonifera & 4 & - & 5 & - & - & 9 \\
\hline Varicosporiumelodeae & - & - & 2 & - & 2 & 4 \\
\hline Zoopagenitospora & - & - & - & 1 & - & 1 \\
\hline Aspergellusrepens & - & - & - & 1 & 2 & 3 \\
\hline Aureobasidium pullulans & - & 3 & - & - & - & 3 \\
\hline Total & & & & & & 108 \\
\hline
\end{tabular}

Table 8. Occurrence of fungi in tilapia TRC2 vial.

\begin{tabular}{|c|c|c|c|c|c|c|}
\hline Fungi species & Week 1 & Week 2 & Week 3 & Week 4 & Week 5 & Total \\
\hline Penicillium italicum & - & 1 & 6 & 2 & - & 9 \\
\hline Articulospora inflate & - & 3 & 9 & 8 & 8 & 28 \\
\hline Candida sp. & - & 10 & 4 & 1 & - & 15 \\
\hline Aspergillus niger & 16 & - & 1 & - & - & 17 \\
\hline Aureobasidium pullulans & - & 2 & - & - & - & 2 \\
\hline Rhodoturula sp. & 8 & 7 & 3 & - & - & 18 \\
\hline Aspergillus flavus & - & - & 11 & 14 & 3 & 28 \\
\hline Rhizopus stolonifera & 3 & - & - & - & - & 3 \\
\hline Varicosporiumelodeae & - & - & 3 & - & 2 & 5 \\
\hline Zoopagenitospora & - & - & - & 1 & 10 & 11 \\
\hline Aspergellusrepens & - & - & - & 7 & - & 7 \\
\hline Total & & & & & & 143 \\
\hline
\end{tabular}


Table 9. Occurrence of fungi in tilapia TRC3 vial.

\begin{tabular}{|c|c|c|c|c|c|c|}
\hline Fungi species & Week 1 & Week 2 & Week 3 & Week 4 & Week 5 & Total \\
\hline Penicillium italicum & - & - & 9 & - & - & 9 \\
\hline Articulospora inflate & - & 10 & 9 & 6 & 6 & 31 \\
\hline Candida sp. & - & 13 & 8 & - & - & 21 \\
\hline Aspergillus niger & 9 & 2 & - & - & - & 11 \\
\hline Rhodoturula sp. & 9 & 3 & 4 & - & - & 16 \\
\hline Mucormucedo & - & 1 & - & - & 2 & 3 \\
\hline Aspergillus flavus & - & - & 19 & - & 3 & 22 \\
\hline Rhizopus stolonifera & 4 & 2 & - & - & - & 6 \\
\hline Aureobasidium pullulans & 6 & 2 & - & - & - & 8 \\
\hline Aspergellusrepens & - & - & - & - & 6 & 6 \\
\hline Total & & & & & & 133 \\
\hline
\end{tabular}

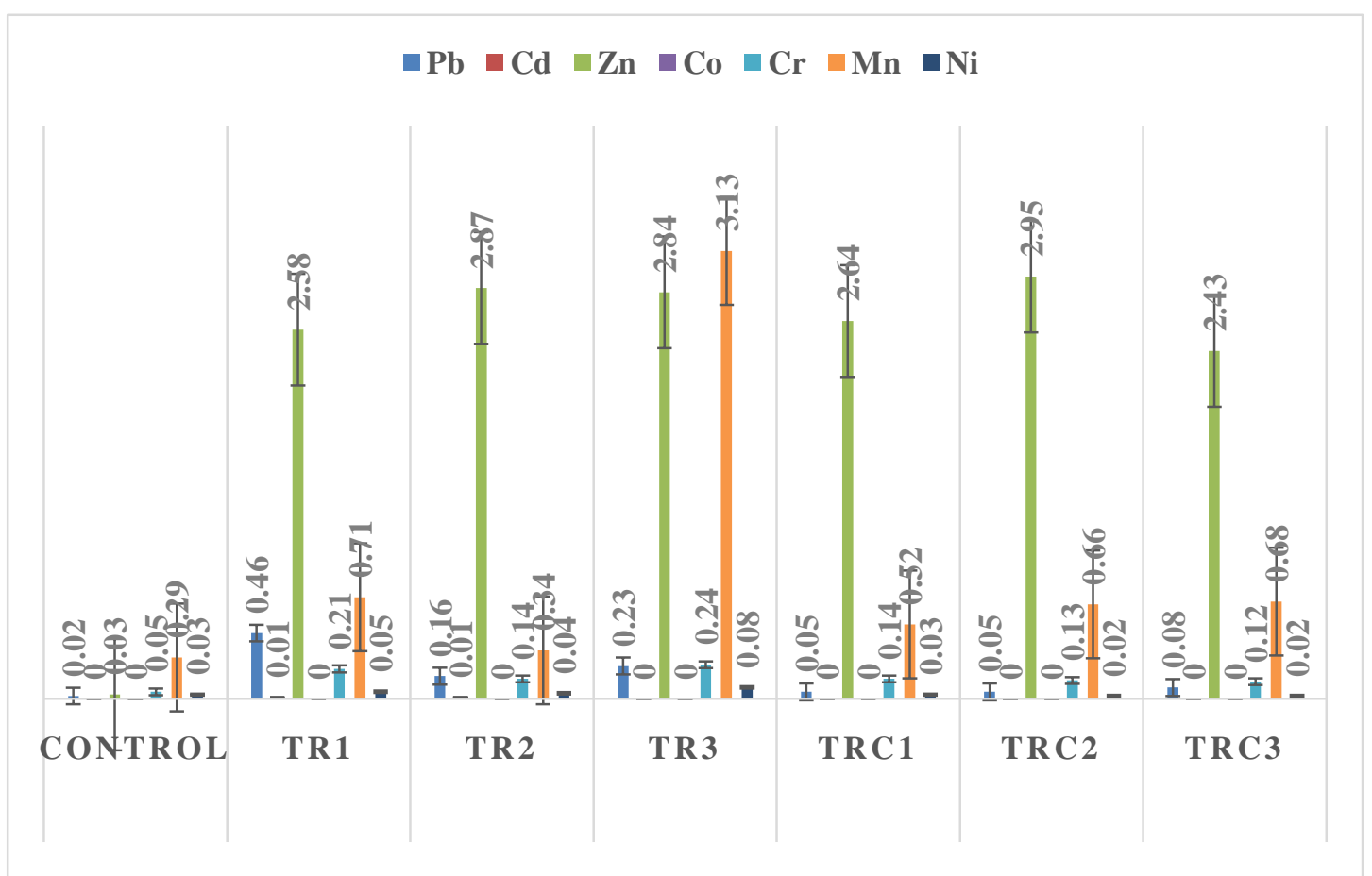

Figure 2. Heavy metal composition of harvested tilapia fish tissue (mg/L). Key: TR1-Treated with $25 \mathrm{~g}$ of e-waste soil, TR2 - Treated with $50 \mathrm{~g}$ of e-waste soil, TR3-Treated with $75 \mathrm{~g}$ of e-waste soil; TRC1-Treated with $25 \mathrm{~g}$ of soil without e-waste, TRC2-Treated with $50 \mathrm{~g}$ of soil without e-waste, TRC3 - Treated with $75 \mathrm{~g}$ of soil without e-waste.

persisted in their habitat. Tilapia fish is possibly at a great risk of manganese toxicity since this was present beyond the recommended tolerable standard. Consumption of heavy metal-contaminated fish by human can lead to heavy metal toxicity in man. These metals can cause gastric and esophageal ulceration in humans and animals. The Agency for Toxic Substances and Disease Registry suggests that ingesting high levels of zinc for several months may cause anemia, damage to the pancreas, and decreased levels of high density lipoprotein. High levels of manganese can cause lung, liver, and vascular disturbances, declines in blood pressure, reproductive abnormalities, and brain damage. Since electrical/electronic equipment and gadgets are also necessary, there should be 


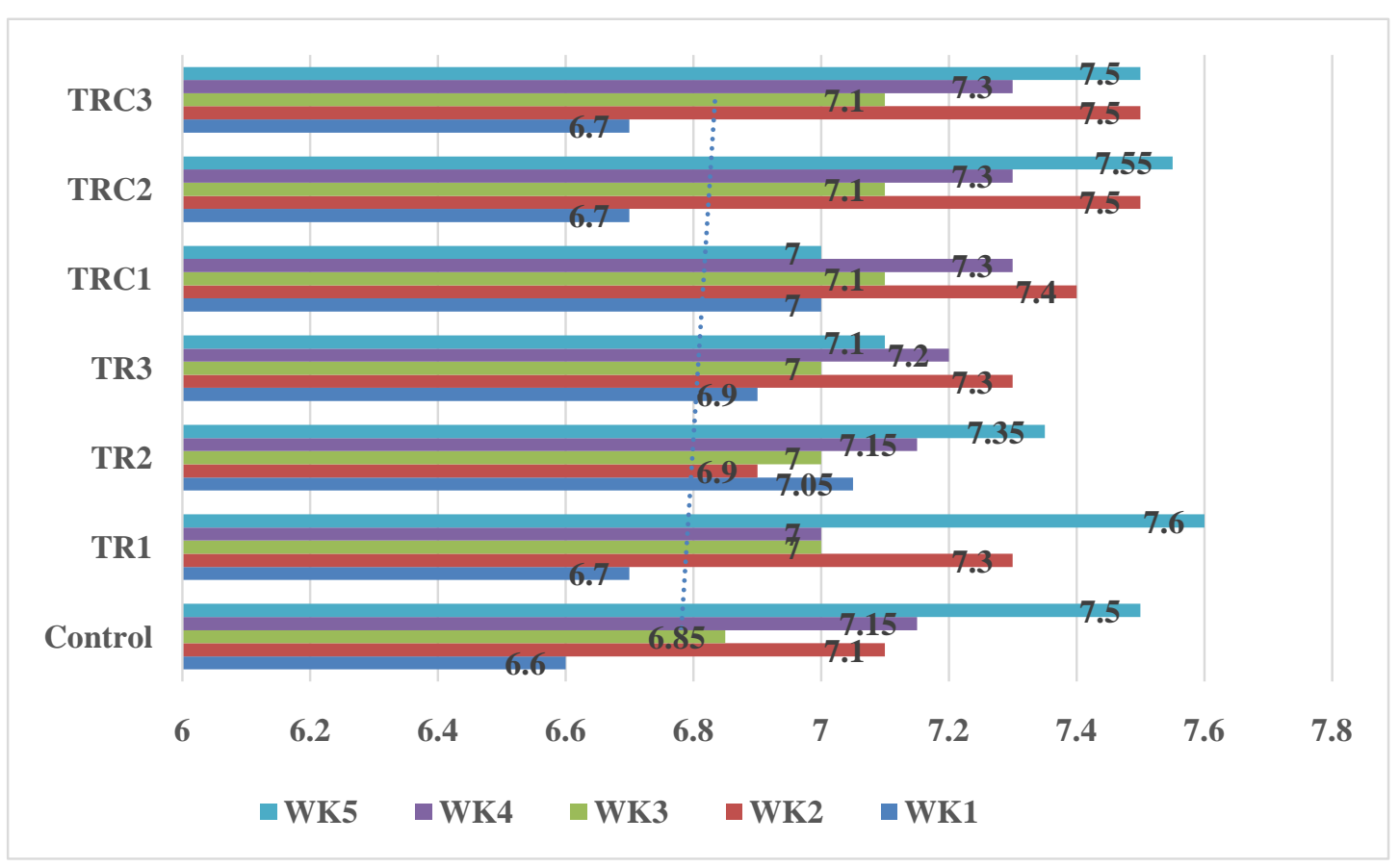

Figure 3. Weekly pH of tilapia vials.

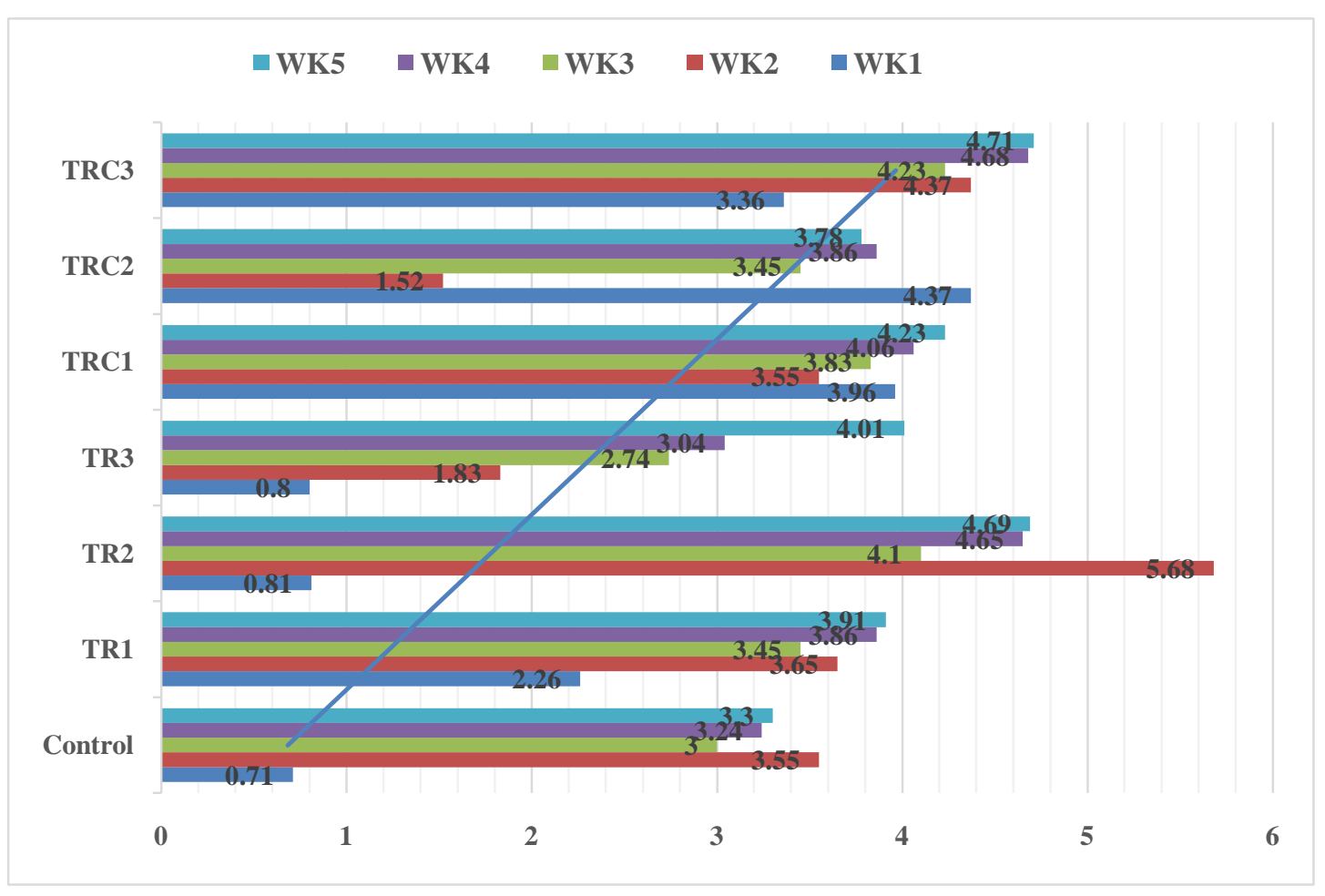

Figure 4. Weekly biochemical oxygen demand of tilapia vials (mg/l).

guidelines laid down for the proper disposal of e-waste, if they are not recycled.

\section{Acknowledgements}

The author is grateful to the Department of Microbiology and the Department of Fish and Aquaculture Tech- 
nology, Federal University of Technology, Akure, Ondo State, Nigeria for providing a conducive research environment and items used for this study.

\section{References}

[1] Gaidajis, G., Angelakoglou, K. and Aktsoglou, D. (2010) E-Waste: Environmental Problems and Current Management. Journal of Engineering science and Technology, 3, 193-199.

[2] Yuan, C., Zhang, H.C., McKenna, G., Korzeniewski, C. and Li, J. (2007) Experimental Studies on Cryogenic Recycling of Printed Circuit Board. International Journal of Advanced Manufacturing Technology, 34, 657-666. http://dx.doi.org/10.1007/s00170-006-0634-z

[3] Javed, M. and Usmani, N. (2011). Accumulation of Heavy Metals in Fishes: A Human Health Concern. International Journal of Environmental Sciences, 2.

[4] Obasohan, E.E. (2008) Heavy Metals Concentrations in the Offal, Gill, Muscle and Liver of a Freshwater Mudfish (Parachanna obscura) from Ogba River, Benin City, Nigeria. African Journal of Biotechnology, 6, 2620-2627. http://dx.doi.org/10.5897/AJB2007.000-2419

[5] Kar, D., Sur, P., Mandal, S.K., Saha, T. and Kole, R.K. (2008) Assessment of Heavy Metal Pollution in Surface Water. International Journal of Environmental Science and Technology, 5, 119-124. http://dx.doi.org/10.1007/BF03326004

[6] Agatha, A.N. (2010) Levels of Some Heavy Metals in Tissues of Bonga Fish, Ethmallosa fimbriata from Forcados River. Journal of Applied Environmental and Biological Sciences, 1, 44-47.

[7] Oronsaye, J.A.O., Wangboje, O.M. and Oguzie, F.A. (2010) Trace Metals in Some Benthic Fishes of the Ikpoba River Dam, Benin City, Nigeria. African Journal of Biotechnology, 9, 8860-8864.

[8] Abdel-Baki, A.S., Dkhil, M.A. and Al-Quraishy, S. (2011) Bioaccumulation of Some Heavy Metals in Tilapia Fish Relevant to Their Concentration in Water and Sediment of Wadi Hanifah. Saudi Arabia African Journal of Biotechnology, 10, 2541-2547.

[9] Ekeanyanwu, C.R., Ogbuinyi, C.A. and Etienajirhevwe, O.F. (2011) Trace Metal Distribution in Fish Tissues, Bottom Sediments and Water from Okumeshi River in Delta State, Nigeria. Environmental Research Journal, 5, 6-10.

[10] WHO (1991) Environmental Health Criteria 108: Nickel. International Programme on Chemical Safety. World Health Organization. http://www.inchem.org/documents/ehc/ehc/ehc108.htm

[11] Wu, J.P., Luo, X.-J., Zhang, Y., Luo, Y., Chen, S.-J., Mai, B.-X. and Yang, Z.-Y. (2008) Bioaccumulation of Polybrominateddiphenyl Ethers (PBDEs) and Polychlorinatedbiphenyls (PCBs) in Wild Aquatic Species from an Electronic Waste (e-Waste) Recycling Site in South China. Elsevier Environmental International Journal, 34, 1109-1113. http://dx.doi.org/10.1016/j.envint.2008.04.001

[12] Voroney, R.P. (2006) The Soil Habitat in Soil Microbiology. Ecology and Biochemistry, 38, 720-728.

[13] Ibitoye, A.A. (2006) Laboratory Manual on Basic Soil Analysis. 2nd Edition, Foladave Publishing Company, Akure, $82 \mathrm{p}$.

[14] Onions, A.H.S., Allospp, D. and Eggins, H.O.W. (1981) Smiths Introduction to Industrial Mycology. 7th Edition, Edward Arnold (Publisher) Ltd., London.

[15] AOAC (2012) Official Method of Analysis: Association of Analytical Chemists. 19th Edition, Washington DC, 121130.

[16] Ademoroti, C.M.A. (1996) Environmental Chemistry and Toxicology. Foludexpress Ltd., Ibadan, 79-121.

[17] Lacatusu, R. (2000) Appraising Levels of Soil Contamination and Pollution with Heavy Metals. In: Heineke, H.J., Eckelmann, W., Thomasson, A.J., Jones, R.J.A., Montanarella, L. and Buckley, B., Eds., European Soil Bureau-Research Report No. 4, 393-403.

[18] American Public Health Association (APHA) (2005) Standard Methods for the Examination of Water and Wastewater Analysis. American Water Works Association/Water Environment Federation, Washington DC, 289.

[19] Hendershot, W.H., Lalande, H. and Duquette, M. (1993) Soil Reaction and Exchangeable Acidity. In: Carter, M.R., Ed., Soil Sampling and Methods of Analysis, Lewis Publisher, Boca Raton, 141-165.

[20] Adegunloye, D.V. and Sanusi, A.I. (2015) Bioaccumulation of Heavy Metals by Catfish (Clarias gariepinus) in E-Waste Soil Polluted Aquaria and Associated Fungi. Current Trends in Technology and Sciences, 4, 450-458.

[21] Aimee, K.Z., Molly, B., Wiley, S., Barbara, A.L., Jackie, L.M. and John, R.P. (2003) Risk of Fungemia Due to Rhodotorula and Antifungal Susceptibility Testing of Rhodotorula Isolates. Journal of Clinical Microbiology, 41, 52335235. http://dx.doi.org/10.1128/JCM.41.11.5233-5235.2003

[22] Ashlee, M.E., Richard, L. and Roberto, K. (2008) Ecology and Genomics of Bacillus subtilis. Trends in Microbiology, 16, 269-275. 
[23] Alfreda, O.N. and Ekene, G.O. (2012) Bioremediation of Crude Oil Polluted Soil Using Bacteria and Poultry Manure Monitored through Soybean Productivity. Polish Journal of Environmental Studies, 21, 171-176.

[24] Krijgsheld, P., Bleichrodt, R., Van Veluw, G.J., Wang, F., Muller, W.H., Dijksterhuis, J. and Wosten, H.A.B. (2013) Development in Aspergillus. Studies in Mycology, 74, 1-29. http://dx.doi.org/10.3114/sim0006

[25] Margesin, R. and Schinner, F. (1997) Efficiency of Indigenous and Inoculated Cold-Adapted Soil Microorganisms for Biodegradation of Diesel Oil in Alpine Soils. Applied and Environmental Microbiology, 63, 2660-2664.

[26] Thippeswamy, B., Shivakumar, C.K. and Krishnappa, M. (2012) Bioaccumulation Potential of Aspergillus niger and Aspergillus flavus for Removal of Heavy Metals from Paper Mill Effluent. Journal of Environmental Biology, 33, 1063-1068.

[27] Mishra, A. and Malik, A. (2012) Simultaneous Bioaccumulation of Multiple Metals from Electroplating Effluent Using Aspergillus lentulus. Water Research, 46, 4991-4998. http://dx.doi.org/10.1016/j.watres.2012.06.035

[28] Kamika, I. and Momba, M.N. (2013) Assessing the Resistance and Bioremediation Ability of Selected Bacterial and Protozoan Species to Heavy Metals in Metal-Rich Industrial Wastewater. BMC Microbiology, 13, 28. http://dx.doi.org/10.1186/1471-2180-13-28

[29] Salvadori, M.R., Ando, R.A., Oller do Nascimento, C.A. and Benedito, C. (2014) Intracellular Biosynthesis and Removal of Copper Nanoparticles by Dead Biomass of Yeast Isolated from the Wastewater of a Mine in the Brazilian Amazonia. PLOS ONE, 9, e87968.

[30] Oguzie, F.A. (2003) Heavy Metals in Fish, Water and Effluents of Lower Ikpoba River in Benin City, Nigeria. Pakistan Journal of Science and Industrial Research, 46, 156-160.

[31] Ballantyne, B. and Marrs, T. (1987) Clinical and Experimental Toxicology of Cyanides. Wright Publishers, Bristol, 451-466.

[32] F.E.P.A. (Federal Environmental Protection Agency) (2003) Guidelines and Standards for Environmental Pollution Control in Nigeria. $238 \mathrm{p}$.

[33] Arotupin, D.J., Fabunmi, T.B. and Ogunmolu, F.E. (2012) Microorganisms, Proximate and Anti-Nutrient Content of Fermenting Kolanut (Cola nitida Vent Schott and Endel) White Shell. FUTA Journal of Research in Sciences, 8, 7582.

\section{Submit or recommend next manuscript to SCIRP and we will provide best service for you:}

Accepting pre-submission inquiries through Email, Facebook, Linkedin, Twitter, etc A wide selection of journals (inclusive of 9 subjects, more than 200 journals)

Providing a 24-hour high-quality service

User-friendly online submission system

Fair and swift peer-review system

Efficient typesetting and proofreading procedure

Display of the result of downloads and visits, as well as the number of cited articles

Maximum dissemination of your research work

Submit your manuscript at: http://papersubmission.scirp.org/ 